\title{
Indeks Massa Tubuh dengan Keseimbangan Statis Pengguna Transtibial Prosthesis
}

\author{
Nur Rachmat ${ }^{1}$, Muhammad Syaifudin ${ }^{2}$, Hanifah $^{3}$ \\ ${ }^{1,2,3}$ Jurusan Ortotik Prostetik, Politeknik Kesehatan Surakarta \\ Email: nurrachmat@gmail.com
}

\begin{abstract}
Body Mass Index with Static Balance of Transtibial Prosthesis User. The balance of a person's body is affected by the Body Mass Index. Body Mass Index is the easiest way to estimate obesity as well as to be highly correlated with body fat mass, but it is also important to identify obese patients who have a risk of medical complications. Purpose of this study was to know correlation body mass index with the static balance of transtibial prosthesis user. The study was a quantitative research with a cross-sectional design. Location research in BBRSBD Prof. Dr. Soeharso Surakarta with sample were patients with post-amputation of transtibial as many as 15 people. Analysis of data was used correlation Pearson test. There was a correlation between body mass index with the static balance of transtibial prosthesis user, the coefficient correlation of 0.646 with significant and levels of correlation moderate. The value of normal body mass index has the highest static balance than lean body mass index and fat. Mass Index of the skinny body has a moderate static balance. Obese body mass index has the lowest static balance of body mass index thin and normal.
\end{abstract}

Keywords: Amputation, BMI, Static Balance, Transtibial Prosthesis

\begin{abstract}
Abstrak: Indeks Massa Tubuh dengan Keseimbangan Statis Pengguna Transtibial Prosthesis. Keseimbangan tubuh seseorang dipengaruhi oleh Indeks Massa Tubuh. Indeks Massa Tubuh adalah cara termudah untuk memperkirakan obesitas serta berkolerasi tinggi dengan massa lemak tubuh, selain itu juga penting untuk mengidentifikasi pasien obesitas yang mempunyai risiko komplikasi medis (Pudjiadi et al, 2010). Tujuan dilakukan penelitian adalah untuk mengetahui hubungan indeks massa tubuh dengan keseimbangan statis pengguna transtibial prosthesis. Jenis penelitian ini adalah penelitian kuantitatif dengan rancangan cross sectional. Lokasi penelitian di BBRSBD Prof. Dr. Soeharso Surakarta dengan sampel adalah pasien pasca amputasi transtibial sebanyak 15 orang. Analisis data menggunakan uji korelasi pearson. Terdapat korelasi antara indeks massa tubuh dengan keseimbangan statis pengguna transtibial prosthesis, dengan koefisien korelasi sebesar -0.646 dengan tingkat hubungan sedang dan signifikan. Maka dapat disimpulkan Indeks Masa Tubuh berhubungan dengan Keseimbangan statis pengguna transtibial prostetis. Nilai Indeks Massa Tubuh normal memiliki keseimbangan statis paling tinggi dari nilai Indeks Massa Tubuh kurus dan gemuk. Nilai Indeks Massa Tubuh kurus memiliki keseimbangan statis sedang.Indeks Massa Tubuh gemuk memiliki keseimbangan statis paling rendah dari nilai Indek Massa Tubuh kurus dan normal.
\end{abstract}

Kata kunci: Amputasi, IMT, Keseimbangan statis, Transtibial Prosthesis

Amputasi merupakan hal yang tidak pernah terpikirkan oleh siapapun, terlebih amputasi pada anggota gerak bawah yang sangat mempengaruhi kehidupan seseorang, sehingga menyebabkan hilangnya fungsi anggota gerak bawah sebagai tumpuan utama untuk aktifitas. Amputasi terjadi karena trauma, infeksi, gangguan metabolisme, kelainan sejak lahir atau conginental, serta kecelakaan kerja. Hilangnya salah satu atau keduanya dari anggota alat gerak bawah menyebabkan menurunnya kemampuan seseorang untuk melakukan suatu aktivitas. Berdasarkan penelitian pada saat ini amputasi pada alat gerak bawah mencapai $85 \%-90 \%$ dari seluruh amputasi dan amputasi bawah lutut (transtibial amputation) merupakan jenis operasi amputasi yang paling sering dilakukan (Tooms R.E, 1992).

Amputasi anggota gerak bawah mengakibatkan terganggunya fungsi ekstremitas, salah satunya adalah fungsi keseimbangan. Keseimbangan juga bisa diartikan sebagai kemampuan relatif untuk mengontrol pusat massatubuh (center of mass) atau pusat gravitasi (center of gravity) terhadap bidang tumpu (base of support).

Keseimbangan tubuh seseorang dipengaruhi oleh Indeks Massa Tubuh. Indeks Massa Tubuh adalah cara termudah untuk memperkirakan obesitas serta berkolerasi tinggi 
dengan massa lemak tubuh, selain itu juga penting untuk mengidentifikasi pasien obesitas yang mempunyai risiko komplikasi medis (Pudjiadi et al, 2010).

Berdasarkan hasil penelitian yang dilakukan oleh (Greve et al, 2007) didapatkankorelasi yang tinggi antara IMT dengan keseimbangan pada usia 20-40 tahun.

Berdasarkan uraian tersebut penulis tertarik untuk melakukan penelitian dengan judul "Hubungan Indeks Massa Tubuh dengan Keseimbangan Statis Pengguna Transtibial Prosthesis".

\section{METODE}

Penelitian dilakukan di rumah pengguna transtibial prosthesis yang merupakan subjek bed side teaching Jurusan Ortotik Prostetik Poltekkes Kemenkes Surakarta periode 2015-2016 dan di BBRSBD Prof. Dr. Soeharso Surakarta pada bulan Mei 2017 s/d Juni 2017. Penelitian ini menggunakan metode penelitian kuantitatif dengan jenis penelitian explanatory menggunakan pendekatan cross sectional. Besar sampel ditentukan oleh purposive sampling. Subjek yang diikutsertakan berjumlah 35 orang dan yang memenuhi kriteria inklusi sejumlah 15 orang.Penelitian ini menggunakan teknik pengambilan data berupa wawancara dan pemeriksaan. Variabel dalam penelitian ini yaitu (1) variabel terikat yaitu Keseimbangan statis pengguna transtibial prosthesis, (2) variabel bebas yaitu Indeks Massa Tubuh pengguna transtibial prosthesis. IMT diambil dengan cara menimbang berat badan dan mengukur tinggi badan subjek tanpa menggunakan prosthesis. Kemudian IMT di impretasikan menjadi klasifikasi IMT menurut WHO tahun 2004, merupakan data interval. Keseimbangan statis diambil dengan cara subjek berdiri tegak dan nyaman pada kedua kaki tanpa alas kaki, memastikam subjek berada didekat alat bantu penopang, kemudian subjek diintruksikan untuk mengangkat kaki yang sehat sampai membentuk sudut $90^{\circ}$, menghitung waktu kemampuan berdiri subjek pada prosthesis menggunakan stopwatch, Tes selesai jika prosthesis yang menumpu bergerak dan kaki yang diangkat menyentuh lantai, mencatat hasil standing stork test paada blanko penelitian. Kemudian hasil standing stork test di impretasikan menjadi klasifikasi standing stork test menurut Schell tahun 1994, merupakan data interval.

Untuk mengetahui hubungan indeks massa tubuh dengan keseimbangan statis, menggunakan uji hipotesis berupa uji spearman rho untuk menentukan adakah hubungan dari variabel bebas dan terikat.

\section{HASIL}

\section{Karakteristik Responden}

Tabel 1. Distribusi Frekuensi Jenis Kelamin

\begin{tabular}{lrr}
\hline Jenis Kelamin & \multicolumn{1}{c}{ f } & \multicolumn{1}{c}{ \% } \\
\hline Laki-laki & 10 & 66.7 \\
Perempuan & 5 & 33.3 \\
\hline Total & 15 & 100.0 \\
\hline
\end{tabular}

Hasil pengumpulan data dari tabel 1 menunjukan bahwa responden laki-laki lebih banyak dibandingkan dengan responden perempuan.

\section{Tabel 2. Distribusi FrekuensiUsia}

\begin{tabular}{crr}
\hline Kelompok Usia & f & \multicolumn{1}{c}{$\%$} \\
\hline 20 & 2 & 13.3 \\
23 & 1 & 6.7 \\
25 & 3 & 20.0 \\
26 & 2 & 13.3 \\
29 & 1 & 6.7 \\
32 & 1 & 6.7 \\
34 & 1 & 6.7 \\
36 & 1 & 6.7 \\
37 & 1 & 6.7 \\
48 & 1 & 6.7 \\
50 & 1 & 6.7 \\
\hline Total & 15 & 100.0 \\
\hline
\end{tabular}

Hasil pengumpulan data pada tabel 2 memperlihatkan bahwa responden terbanyak pada usia 25 tahun yaitu sejumlah 3 responden $(20 \%)$.

\section{Karakteristik Variabel}

Tabel 3. Distribusi Indeks Massa Tubuh

\begin{tabular}{lrr}
\hline Klasifikasi IMT $\left(\mathbf{k g} / \mathbf{m}^{2}\right)$ & \multicolumn{1}{c}{ f } & \multicolumn{1}{c}{$\%$} \\
\hline Kurus & 3 & 20.0 \\
Normal & 7 & 46.7 \\
Gemuk & 5 & 33.3 \\
\hline Total & 15 & 100.0 \\
\hline
\end{tabular}

Tabel 3 menunjukkan bahwa responden terbanyak dalam penelitian ini adalah pada kategori Indeks Massa Tubuh (IMT) normal, yaitu sebanyak 7 responden $(46,7 \%)$.

Tabel 4. Distribusi Keseimbangan Statis

\begin{tabular}{ccc}
\hline Keseimbangan Statis & f & $\%$ \\
\hline Poor & 6 & 40.0 \\
Below Average & 9 & 60.0 \\
\hline Total & 15 & 100.0 \\
\hline
\end{tabular}


Tabel di atas menunjukan bahwa responden terbanyak adalah pada kategori keseimbangan statis below average, yaitu sebanyak 9 responden $(60 \%)$.

\section{Uji Hipotesis}

Tabel 5. Korelasi Indeks Massa Tubuh dengan Keseimbangan Statis

\begin{tabular}{|c|c|c|c|c|}
\hline & & & IMT & KS \\
\hline \multirow{6}{*}{$\begin{array}{l}\text { Spearman's } \\
\text { rho }\end{array}$} & IMT & Correlation & 1 & -.646 \\
\hline & & $\begin{array}{l}\text { Coefficient } \\
\text { Sig (2-tailed) }\end{array}$ & & \\
\hline & \multirow{4}{*}{ KS } & $\mathrm{N}$ & 15 & 15 \\
\hline & & Correlation & -.646 & \\
\hline & & Sig. (2-tailed) & .009 & \\
\hline & & $\mathrm{N}$ & 15 & 15 \\
\hline
\end{tabular}

Output data di atas menunjukkan bahwa nilai Sig. (2-tailed) atau nilai $p$ adalah 0.009 $(p<0,05)$, sehingga diketahui bahwa terdapat hubungan yang signifikan antara Indeks Massa Tubuh dengan Keseimbangan Statis pada pengguna Transtibial Prostesis. Angka Correlation Coefficient (koefisien korelasi) sebesar -0.646, menunjukkan adanya hubungan yang sedang antara Indeks Massa Tubuh dengan Keseimbangan Statis pada pengguna trasntibial prosthesis.

\section{PEMBAHASAN}

Karakteristik jenis kelamin responden berdasarkan tabel 1 jumlah responden laki-laki lebih banyak dari perempuan.

Karakteristik responden berdasarkan usia menunjukkan bahwa responden terbanyak pada penelitian ini adalah pada kelompok usia 25 tahun yang berjumlah 3 orang.

Distribusi responden berdasarkan IMT menunjukkan bahwa, jumlah responden yang memiliki nilai IMT ideal lebih banyak daripada yang memiliki nilai IMT gemuk dan kurus.

Dalam penelitian ini berdasarkan kategori IMT dan kategori keseimbangan statis didapatkan hasil yaitu sebanyak 3 responden dengan kategori kurus, dimana keseluruhannya berada pada kategori keseimbangan statis di bawah rata-rata, dengan durasi waktu kemampuan lama berdiri dengan satu kaki pada transtibial prosthesis yaitu antara 3.6-4.5 detik. Responden dengan kategori Indeks Massa Tubuh normal yang berjumlah 7 orang, berada pada kategori keseimbangan statis dibawah rata-rata dengan durasi waktu lama berdiri yaitu 5-6.5 detik, sisanya sebanyak 5 orang berada pada kategori keseimbangan statis buruk dengan durasi waktu kemampuan berdiri di bawah 3 detik.

Uji statistik korelasi yaitu dengan uji analisis spearman's rho didapatkan hasil nilai Sig. (2-tailed) atau nilai p adalah $0.009(p<0,05)$, yang berarti variabel Indeks Massa Tubuh memiliki hubungan dengan keseimbangan Statis pada pengguna transtibial Prostesis. Nilai koefisien korelasi-0.646 yang berarti Indeks Massa Tubuh memiliki hubungan yang sedang terhadap Keseimbangan statis pada pengguna transtibial prostesis. Setelah melihat grafik klasifikasi antara Indeks Massa Tubuh dengan Keseimbangan Statis pada pengguna transtibial prosthesis dari hasil tabulasi data yang dapat dilihat pada gambar 1, diketahui bahwa pada nilai Indeks Massa Tubuh normal memiliki keseimbangan statis paling tinggi dari nilai Indeks Massa Tubuh kurus dan gemuk. Nilai Indeks Massa Tubuh kurus memiliki keseimbangan statis sedang. Indeks Massa Tubuh gemuk memiliki keseimbangan statis paling rendah dari nilai IMT kurus dan normal.

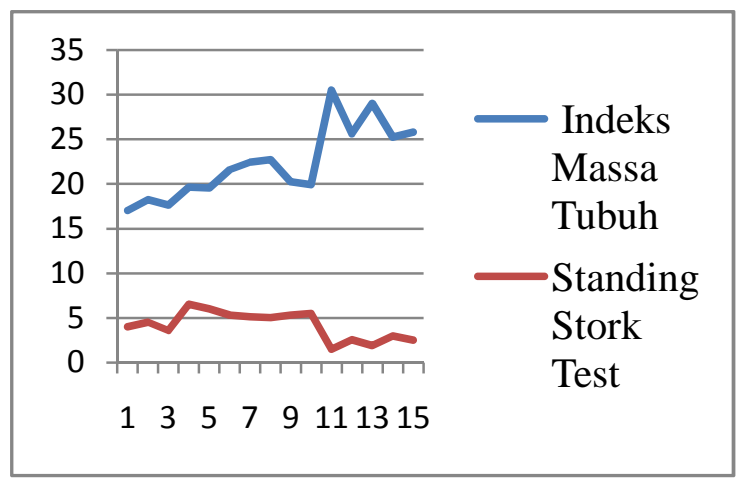

\section{Gambar 1. Indeks Massa Tubuh dengan Keseimbangan Statis pada Pengguna Transtibial Prosthesis}

Hasil penelitian ini mendukung penelitian terdahulu dari M. Syaifuddin (2016) bahwa terdapat hubungan antara keseimbangan berjalan yang dilihat dari panjang stump dan IMT yang secara statistik signifikan $(p=0,005)$. Greve $\mathrm{J}$ et al (2007) Hasil yang diperoleh menunjukkan bahwa ada korelasi indeks massa tubuh terhadap keseimbangan postural, dimana Indeks Massa Tubuh berpengaruh terhadap keseimbangan seseorang, semakin tinggi IMT seseorang maka akan semakin sulit untuk medapatkan keseimbangan. Porto et al (2012)bahwa pada subyek yang termasuk obesitas memiliki tingkat keseimbangan yang kurang dibanding dengan subjek Indeks Masa Tubuh ideal. 


\section{SIMPULAN}

Indeks Masa Tubuh memiliki hubungan yang sedang dengan Keseimbangan Statis pengguna transtibial prosthesis.

Pada nilai Indeks Massa Tubuh normal memiliki keseimbangan statis paling tinggi dari nilai Indeks Massa Tubuh kurus dan gemuk. Nilai Indeks Massa Tubuh kurus memiliki keseimbangan statis sedang. Indeks Massa Tubuh gemuk memiliki keseimbangan statis paling rendah dari nilai IMT kurus dan normal.

\section{SARAN}

Bagi pengguna transtibial prosthesis sebaiknya melakukan latihan dan tetap menjaga indeks massa tubuh dalam kategori normal guna menjaga keseimbangan statis.

Bagi peneliti selanjutnya hendaknya melakukan penelitian lanjutan dengan melakukan penelitian mengenai faktor lain dengan subjek yang lebih banyak, frekuensi jenis kelamin lebih seimbang, tingkat aktifitas dan pekerjaan subjek lebih dikontrol, memperhatikan jenis prostesisnya, memperhatikan ukuran MMT dan Rom tungkai responden.

\section{DAFTAR PUSTAKA}

Tooms R.E. Crenshaw, M.D. 1992.Amputation of Lower Extremity. In: Campbell's.

Pudjiati, Antonius et al. 2010. Pedoman Pelayanan Medis Ikatan Dokter Anak Indonesia. Jilid I. Jakarta: Pengurus Pusat Ikatan Dokter Anak Indonesia.

Schell, J. and Leelarthaepin, B. 1994. Physical Fitness Assessment in Exercise and Sports Science. 2nd Ed, Leelar Biomedisience Services, Matraville, NSW. p. 327.
Greve J., Alonso A., Ana., Bordini P.G and Camanho, L.G. 2007.Correlation Between Body Mass Index And Postural Balance. Clinics 2007;62(6):717-20.

Syaifuddin, M. 2016. Hubungan Panjang Puntung dan Indeks Massa Tubuh dengan Keseimbangan Berjalan pada Pasien Pasca Amputasi Anggota Gerak Bawah. Momentum, Vol. 12, No. 2 (2016), Hal. 13-16. 